\title{
Implementation of Unprocessed Dried Horse Manure Ash in Sustainable Concrete
}

\author{
Rustam Sahu ${ }^{1 *}$ and Abhishek Tiwari ${ }^{2}$ \\ 'Department of Civil Engineering, Sagar Institute of Science Technology and Research, Bhopal - 462044, \\ Madhya Pradesh, India; rustamplanex@outlook.com \\ 2Department of Civil Engineering, Jabalpur Engineering College, Jabalpur - 482011, Madhya Pradesh, India; \\ tiwariabhishek2609@gmail.com
}

\begin{abstract}
Objectives: To examine the strength characteristics of the given grade of concrete after partial replacement of the cement $(5 \%, 10 \%, 15 \%$ and $20 \%)$ as well as partial replacement of the sand $(5 \%, 10 \%, 15 \%$ and $20 \%)$ by Horse Manure Ash (HMA). Methods/Statistical Analysis: Implementation of HMA as an admixture, in the direction of producing high strength concrete is a novel approach. This paper presents change in the properties and in the behavior of concrete, with and without using HMA. In and all 72 specimens with proposed M30 grade mix were casted and tested. Slump tests and compaction factor tests were used to determine the workability of the green concrete. The compressive strength of cube blocks was obtained at 7 and 28 days and the flexural strength of prism blocks was obtained at 28 days for the determination of strength characteristics. Findings: In most of the previous research works authors have made attempts to incorporate several supplements for the cement and aggregates like that of fly ash, clay, slag etc. and natural as well as synthetic fibres like that of the fibres obtained from steel, glass, metals, coir, jute, plastic, rice husk, straw etc. into the concrete. Dried horse manure and its ash produced after burning was never used for research purpose. The experiments performed for the present research work have shown that the addition of HMA as an admixture in concrete mix showed encouraging and interesting results when tested at 28 days. The best possible replacement of HMA in concrete without affecting target mean strength was found to be up to $10 \%$ for cement replacement and $15 \%$ for sand replacement. The workability of the designed concrete mix increases continuously up to the $20 \%$ replacement of sand as well as of cement by HMA. The maximum compressive strength and flexural strength at 28 days of concrete was found when cement is replaced up to $5 \%$ and sand is replaced up to $10 \%$ by HMA in concrete mix. Application/Improvements: Horse manure is a natural organic waste obtained in huge amount from the defence areas and other sports campuses. This waste can be successfully utilized for the production of high strength concrete.
\end{abstract}

Keywords: Compressive Strength, Fibre Reinforced Concrete, Flexural Strength, Horse Manure Ash, Sustainable Concrete, Workability

\section{Introduction}

In recent times the production of renewable energy with agricultural biomass becomes more significant. Therefore, the consumption of agricultural byproducts is vital step for the future sustainable development. Utilization of fly ash has now been used since past few decades has already attained pace in the construction industry. Numerous types of ashes with their inventive varieties from the several production areas have always made it an emergent topic for the researchers. For the present study ash produced after the burning of horse manure is used.

*Author for correspondence 
Improper disposal of horse manure causes a threat to the environment. Recycling it can not only protect the local environment but it can also save penny. Spreading horse manure can contribute to harmful urban runoff that contains bacteria and nutrients that pollutes local groundwater. To reduce the impact of agricultural waste byproducts like horse manure on environment, an attempt was previously made which make use of the pulverized horse manure fibres to yield high strength concrete. The accomplishments of the designed sustainable concrete mix with pulverized horse manure fibres was found to be resourceful and were remarkable with compare to the conventional mix ${ }^{1}$.

The horses don't necessarily digest well due to their small stomach. Their dung when comes out, consists of highly compressed grass. It is highly flammable when it is fresh, dry and free from moisture. Thus it can be a good non-conventional fuel source. (https://www.youtube. com/watch?v=z0IrMR8qPfA)

As per the information provided by the Global Expertise of Hallbar Consulting, renewable energy was produced in Ancient Persia and Egypt countries in an efficient and economical manner using sun-dried manure by heating it. (https://www.hallbarconsulting.com/horsemanure-renewable-energy/)

Ashes produced by burning dried horse manure comprises with two different ash content.

- Higher ash content - Horse manure that contains dried pasture, rye, oat, wheat, hay, straw etc. are very difficult to use for the production of renewable energy as it has low ash melting temperature thus produces sticky ashes which adheres to surface and may cause corrosion.

- Lower ash content - Horse manure that contains woody material, flax, pellets, saw dust, wood shavings etc. are considerably more conducive for the production of renewable energy as it has high ash melting temperature. Thus it is beneficial in the easier, cheaper and economically feasible production.

In past decades, many researchers tried to develop various method of combustion of horse manure. In this property that makes the possibility of burning them in an arable land by adopting methods such as in wood chip boiler 5 .

There are so many sports centers and military training campuses in India that have horses in abundance and they utilize its byproduct i.e. horse manure as a fuel. Literature is still lacking information about the burning of horse manure in such parts of India.

In terms of global considerations, the research works have proven that there are some parts in the world where horse manure is used as a fuel in small scale heating plant by co-combustions $\frac{6,7}{2}$. On the basis of environmental problem at the area of intensive agricultural production like in the vicinity of Baltic Sea Region of Atlantic Ocean, manure is considered as a waste product. Agricultural and Environmental Researchers from nearby countries of Baltic Sea Region such as Sweden, Finland, and Poland have done research to utilize the manure by adopting various methods of combustion and co-combustion since last few decades ${ }^{8,9}$.

Combustion of horse manure leads to produce solid remains i.e. ash. So researchers can focus on ash residual of such areas/heating plant where horse manure is used for combustion. Thus it may be a burning topic for construction and building material researchers to discover various uses and applications of new building material/ ash i.e. HMA for the future sustainable development.

The present research is focused on utilizations of the fired byproduct of horse manure i.e. HMA on the cement concrete matrix for the better sustainability of the environment. As use of horse manure ash in concrete not only improves the mechanical strength of concrete but also leads to the proper disposal of horse manure ash.

\section{Materials Used and Experimental Programme}

\subsection{Cement}

Ordinary Portland cement confirming the requirements of BIS: $11269-2013^{10}$ was used throughout the experimental program. Ordinary Portland cement of 53 grades used has following properties as mentioned in Table 1. 
Table 1. Physical properties of cement

\begin{tabular}{|c|c|c|}
\hline \multicolumn{2}{|l|}{ Physical Properties } & $\begin{array}{l}\text { Specifications } \\
\text { (Confirming to } \\
\text { BIS:12269-2013) }\end{array}$ \\
\hline \multirow{2}{*}{ Soundness } & Le Chatelier expansion & $0.8 \mathrm{~mm}$ \\
\hline & Auto Clave expansion & $0.062 \%$ \\
\hline \multicolumn{2}{|l|}{ Fineness } & $330 \mathrm{~m}^{2} / \mathrm{kg}$ \\
\hline \multicolumn{2}{|l|}{ Standard Consistency } & $30.5 \%$ \\
\hline \multirow{2}{*}{ Setting time (Vicat Apparatus) } & Initial & 150 minutes \\
\hline & Final & 225 minutes \\
\hline \multirow{3}{*}{ Compressive Strength } & 3 Days & $38.0 \mathrm{MPa}$ \\
\hline & 7 Days & $47.6 \mathrm{MPa}$ \\
\hline & 28 Days & $63.6 \mathrm{MPa}$ \\
\hline \multicolumn{2}{|l|}{ Specific Gravity } & 3.15 \\
\hline
\end{tabular}

\subsection{Aggregates}

The size of fine aggregates used was $4.75 \mathrm{~mm}$ maximum retained at 150 microns. Mixed coarse aggregates of sizes $12 \mathrm{~mm}$ and $20 \mathrm{~mm}$ were used throughout the work. The region at which current experimental program held comes under grading Zone II as per the governing parameters for determining fine and coarse aggregates. Maximum size of both fine and coarse aggregates is validating to Table 2 (clause 4.3) and Table 3 (clause 4.1, clause 4.2) respectively of BIS: 383-1970. The physical tests on aggre-

Table 2. Ingredients used in $\mathrm{kg} / \mathrm{m}^{3}$ of concrete

\begin{tabular}{|c|c|c|}
\hline \multicolumn{2}{|l|}{ Materials } & Proportions \\
\hline \multicolumn{2}{|l|}{ Water (L) } & 160 \\
\hline \multicolumn{2}{|l|}{ Cement (kg) } & 380 \\
\hline \multicolumn{2}{|l|}{ Sand (kg) } & 711 \\
\hline \multirow{2}{*}{ Aggregates $(\mathrm{kg})$} & $10 \mathrm{~mm}$ & 359 \\
\hline & $20 \mathrm{~mm}$ & 924 \\
\hline \multicolumn{2}{|l|}{ Admixture (kg) } & 1.90 \\
\hline \multicolumn{2}{|l|}{$(C: S: A)$} & $1: 1.8: 3.3$ \\
\hline
\end{tabular}


Table 3. Physical Properties of Aggregates

\begin{tabular}{|c|c|c|c|}
\hline \multirow{2}{*}{ Physical Properties } & \multicolumn{2}{|c|}{ Coarse Aggregates } & \multirow{2}{*}{$\begin{array}{c}\text { Fine } \\
\text { Aggregates }\end{array}$} \\
\hline & $10 \mathrm{~mm}$ & $20 \mathrm{~mm}$ & \\
\hline Specific gravity & 2.87 & 2.88 & 2.60 \\
\hline Fineness modulus (mm) & 6.42 & 6.88 & 2.72 \\
\hline Bulk density $\left(\mathrm{kg} / \mathrm{m}^{3}\right)$ & 1630 & 1590 & 1750 \\
\hline Water Absorption (\%) & 0.83 & 0.97 & 1.23 \\
\hline
\end{tabular}

gates are validating to BIS:2386-1963. The properties of fine and coarse aggregates are specifically shown in Table $31 \frac{11,12}{}$.

\subsection{Admixture}

Conplast SP430 G8 was used as an admixture which is made available by Forsoc Chemicals (India) Pvt. Ltd. and it complies well with BS: 5075-3-1985 and code BIS: 9103-1999. The properties of super plasticizer (Conplast) are shown in Table $4^{13,14}$.

Table 4. Properties of Super Plasticizer (Conplast)

\begin{tabular}{|c|c|}
\hline Properties & Remarks \\
\hline Color of Conplast & Brown Solution \\
\hline Specific gravity & 1.25 \\
\hline Chloride content & Nil \\
\hline
\end{tabular}

\subsection{Horse Manure Ash}

To determine the physical and mechanical performance of concrete, horse manure ash was used by the partial replacement of cement as primary intentioned and partial replacement of sand as secondary in the different concrete mixes. For that completely dried horse manure (shown in Figure 1) was burnt in an arable land at a temperature of $600^{\circ} \mathrm{C}-700^{\circ} \mathrm{C}$. The residue of horse manure after burning in the form of ash (shown in Figure 2) was then collected for the experimental studies. The physical properties of its ash shows highly pozzolanic behavior. The specific gravity of horse manure ash was found to be 2.12. The specification of horse manure ash complies with BIS: 3812-2013 ${ }^{15}$.

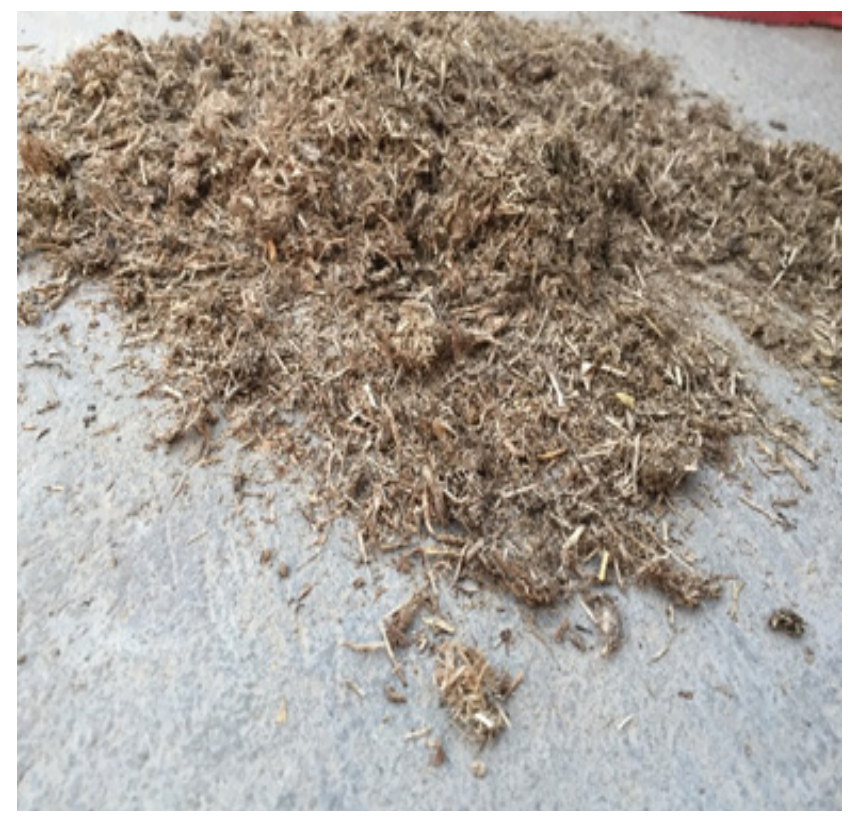

Figure 1. Dried horse manure. 


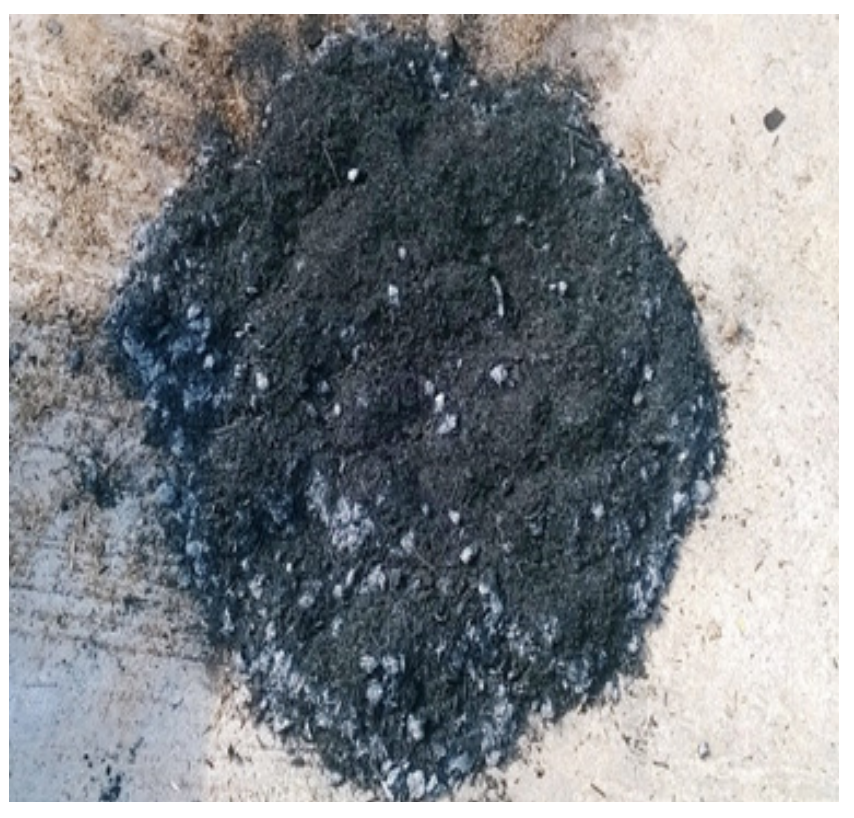

Figure 2. Horse manure ash.

\subsection{Concrete Mix Design}

Grade designation for proposed concrete was M30 as per BIS 10262-2009 \& MORT\&H. The adopted water cement ratio was 0.42 . The proportioning of ingredients used in mix design is given in Table 2 and the proposed mix design parameters for various batches are illustrated in Table $5 \underline{16,17}$.

\subsection{Experimental Program}

In the direction of determining the workability of the designed mix, slump test and the compaction factor test conforming to BIS 516-1959 and BIS 1199-1959 were performed $\frac{18,19}{}$.

7 days and 28 day's compressive strength of cube blocks of side $150 \mathrm{~mm}$ were worked out under Universal Testing Machine of $2000 \mathrm{kN}$ capacity conforming to BIS 516-1959 and BIS 10086-1982. The load applied on cubes was@ $14 \mathrm{~N} / \mathrm{mm}^{2} / \mathrm{min}^{18,20}$.

Flexural Strength test conforming to BIS 516-1959 and BIS 10086-1982 was performed on casted prism blocks of size $(700 \mathrm{~mm} \times 150 \mathrm{~mm} \times 150 \mathrm{~mm})$ at 28 days. The applied load was maintained @ $400 \mathrm{~kg} / \mathrm{min}$ until the specimen failed $\frac{18,20}{}$.

Table 5. Mix Design Parameters

\begin{tabular}{|c|c|c|c|c|c|}
\hline \multirow{2}{*}{ Specimen } & \multirow{2}{*}{ Title } & \multicolumn{2}{|c|}{ Replacement (\%) } & \multirow{2}{*}{$\begin{array}{l}\text { Grade of } \\
\text { Concrete }\end{array}$} & \multirow{2}{*}{$\begin{array}{l}\text { Adopted Mix } \\
\text { Proportion }\end{array}$} \\
\hline & & Cement & Sand & & \\
\hline S1 & $\mathrm{CON}$ & 0 & 0 & \multirow{9}{*}{ M30 } & \multirow{9}{*}{$1: 1.8: 3.3$} \\
\hline S2 & CR-05 & 5 & 0 & & \\
\hline S3 & CR-10 & 10 & 0 & & \\
\hline S4 & CR-15 & 15 & 0 & & \\
\hline S5 & CR-20 & 20 & 0 & & \\
\hline S6 & SR-05 & 0 & 5 & & \\
\hline S7 & SR-10 & 0 & 10 & & \\
\hline S8 & SR-15 & 0 & 15 & & \\
\hline S9 & SR-20 & 0 & 20 & & \\
\hline
\end{tabular}




\section{Discussions on Tests Results}

\subsection{Workability of Fresh Concrete}

As the proportioning of the horse manure ash in the concrete mix is increased, the workability of the concrete

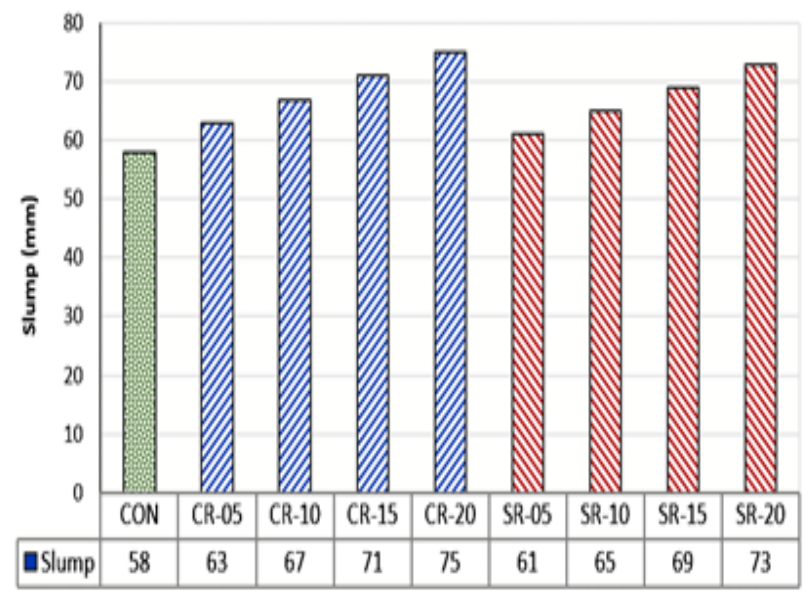

Conventional $\mathbb{Z}$ Cement Replaced

NIV Sand Replaced

Figure 3. Variation in slump value.

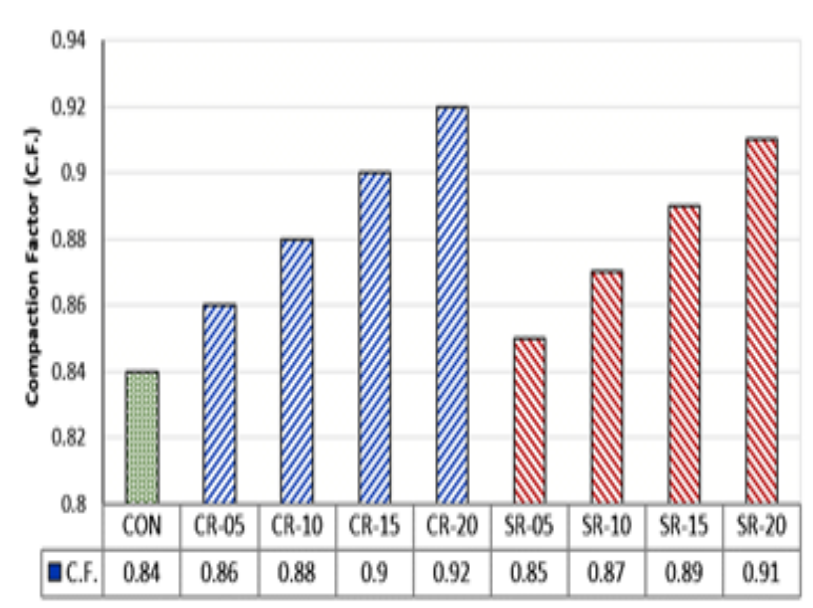

Conventional WIS Cement Replaced

IN Sand Replaced also increases. It is supported by the fact that there is $23 \%$ $\& 21 \%$ increase in the slump value and $9 \%$ \& $8 \%$ increase in the compaction factor value by the replacement of cement up to $20 \%$ and sand up to $20 \%$ respectively. It may be because the HMA obtained from the properly burning of horse manure is of finely powdered form. Its addition helps further in well gradation of concrete and also provide lubricating effect to the concrete mix. The results of fresh concrete by slump test and compaction factor test are represented graphically in Figures 3,4 respectively.

\subsection{Compressive Strength of Cube Blocks}

The replacement of cement up to 5\% by HMA increases the strength at 7 days and 28 days by $5 \%$ whereas the replacement of sand up to $10 \%$ by HMA increases the strength at 7 days and 28 days by $8 \%$. Better workable and well graded concrete with constant $\mathrm{w} / \mathrm{c}$ ratio generally helps in achieving more compressive strength as the voids are minimum in that case. This could be the reason for slight increase in compressive strength for the HMA concrete. The results of compressive strength test are represented graphically in Figures 5 and 6 for 7 days and 28 days respectively.

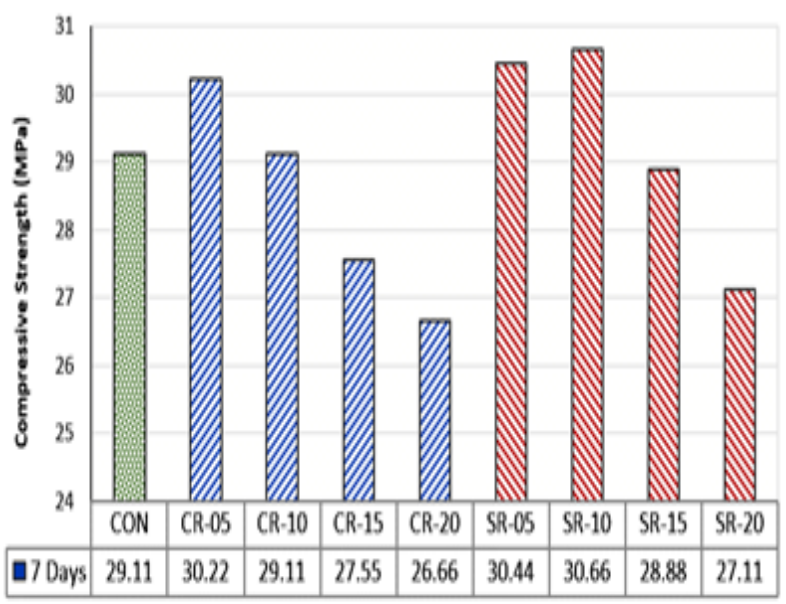

\section{Conventional WII Cement Replaced $\mathbb{N}$ Sand Replaced}

Figure 5. Variation in compressive strength at 7 days. 


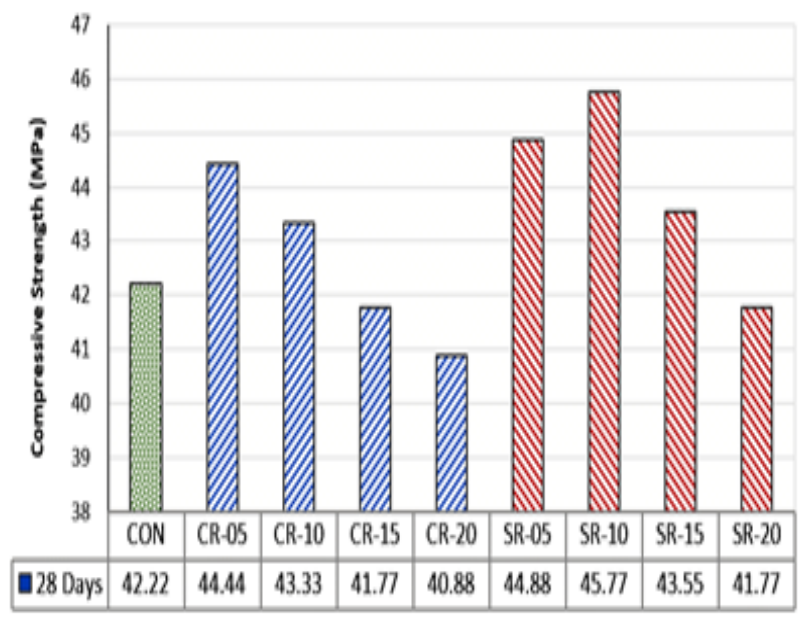

Conventional WII Cement Replaced

$\mathbb{N}$ Sand Replaced

Figure 6. Variation in compressive strength at 28 days.

\subsection{Flexural Strength of Prism Blocks}

The replacement of cement up to $5 \%$ by HMA increases the flexural strength by $4 \%$, whereas the replacement of sand up to $10 \%$ by HMA increases the strength by $6 \%$ at 28 days. The inclusion of ash residue of horse manure and its fibres acts as a reinforcing materials for the concrete.

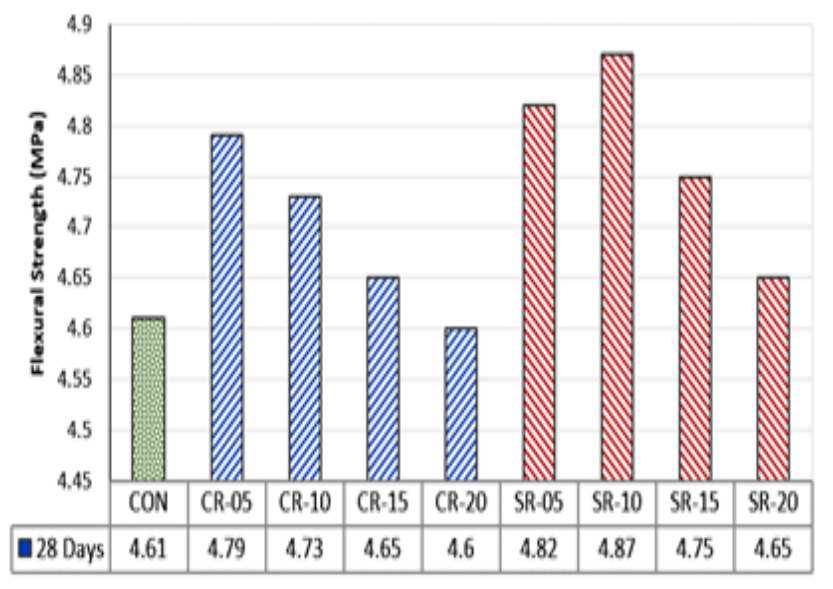

Conventional $\mathbb{Z}$ Cement Replaced

NIV Sand Replaced

Figure 7. Variation in flexural strength at 28 days.
Resultant reinforcement and reduced voids could have helped in enhanced bending and tensile strength of HMA concrete, slightly though. The results of flexural strength test are represented graphically in Figure 7.

\section{Conclusions}

Use of horse manure and its ash is very new in the construction industry. Its application is proved to be advantageous when it was used in soil stabilization, earlier in the year 2017. Now it is being used profitably in concrete mix also. The present study is just a step forward in giving a novel idea of using HMA in conventional concrete and revealing its strength properties. From the present study it can be concluded that:

- When the replacement of cement is increased up to $20 \%$ by HMA in concrete mix, there is increase in slump value by $23 \%$ and increase in compaction factor value by $9 \%$, which shows the workability of the concrete is increased.

- With the replacement of sand up to $20 \%$ by HMA in concrete mix also the workability of the concrete increases as there is increase in $21 \%$ slump value and $8 \%$ in compaction factor value for the same.

- Both compressive strength and flexural strength of concrete increases initially with the inclusion of HMA and then decreases. Maximum compressive strength and flexural strength of concrete at 28 days is found when cement is replaced up to $5 \%$ and sand is replaced up to $10 \%$ by HMA in concrete mix.

- Optimum replacement of HMA in a concrete is found to be $10 \%$ for cement and $15 \%$ for sand replacement without affecting target mean strength of concrete.

- There will be a reduction in cost of material for the same strength of concrete if HMA is introduced 
in it. This is because HMA is a waste and can be obtained free of cost from the dumped site after the utilization of its energy.

\section{References}

1. Sahu R, Tiwari A. Compressive strength of high strength concrete with and without natural organic fibres. International Research Journal of Engineering and Technology. 2017 Jul; 4(7):859-63.

2. Tegeder $M$, Lemmer A, Oechsner $H$, Jungbluth $T$. Investigation of the methane potential of horse manure. Agricultural Engineering International: CIGR Journal. 2013 Jul; 15(2):161-72.

3. Lundgren J, Pettersson E. Practical, environmental and economic evaluation of different options for horse manure management. Proceedings of the 16th International Congress of Chemical and Process Engineering; Czech Republic; 2004.

4. Lawrence L, Bicudo J, Wheeler E. Horse manure characteristic literature and database review. Proceedings of the 9th International Animal, Agricultural and Food Processing Wastes; North Carolina USA; 2003. p. 277-84. Crossref. PMid:12970648

5. Baky A, Karlsson E, Norberg I, Tersmeden M, Yngvesson J. Förbränning av förtorkad hästgödsel på gårdsnivå. Utvärdering av torkningsanläggning och förbränningsegenskaper. Combustion of dried horse manure on farm scale level evaluation of dryer performance and combustion properties. JTI-report: Lantbruk \& Industri Nr. 411; 2012.

6. Lundgren J, Pettersson E. Combustion of horse manure for heat production. Bio Resource Technology. 2009 Jun; 100(12):3121-6. Crossref.

7. Pettersson E, Lundgren J, Hermansson R. Co-combustion of wood shaving and horse manure in a small scale heating plant. Proceedings of World Bioenergy Conference; 2006. p. $396-400$.
8. Tyni SK, Tiainen MS, Laitinen RS. The suitability of horse manure and bedding materials for combustion. Proceedings of the 20th International Conference on Fluidized Bed Combustion; 2009. p. 1130-35. Crossref.

9. Combustion of manure: Manure as a fuel in a heating plant. Baltic Forum for Innovative Technologies for Sustainable Manure Management [Internet]. [cited $2011 \mathrm{Dec}$ ]. Available from:http://balticmanure.odeum.com/download/Reports/ baltic_manure_combustion_final_2_2011_total.pdf.

10. IS 12269-2013. Ordinary Portland Cement- 53 grade specification. Bureau of Indian Standards, New Delhi; 2013. p. $1-4$.

11. IS 383-1970. Specification for coarse and fine aggregates from natural sources for concrete. Bureau of Indian Standards, New Delhi; 1970. p. 7-11.

12. IS 2386-1963. Method of test of aggregates. Bureau of Indian Standards, New Delhi; 1963. p. 4-17.

13. IS 5075-3-1985. Concrete admixtures- Specification for super plasticizing admixtures. British Standards, British Standards Institutions; 1985. p. 1-16.

14. IS 9103-1999. Specification for admixtures for concrete. Bureau of Indian Standards, New Delhi; 1999. p. 1-11.

15. IS 3812-2013. Pulverized fuel ash specification. Bureau of Indian Standards, New Delhi; 2013. p. 1-4.

16. IS 10262-2009. Recommended Guidelines for Concrete Mix Design. Bureau of Indian Standards, New Delhi; 2009. p. $1-11$.

17. Ministry of road transport and highway. Specification for road and bridge work. (Fifth Revision); Indian Road Congress; New Delhi; 2013. p. 1-902.

18. IS 516-1959. Method of test for concrete. Bureau of Indian Standards, New Delhi; 1959. p. 3-17.

19. IS 1199-1959. Method of sampling and analysis of concrete. Bureau of Indian Standards, (Eleventh Reprint NOVEMBER 1991). New Delhi; 1959. p. 4-49.

20. IS 10086-1982. Specifications for moulds for use in test of cement and concrete. Bureau of Indian Standards, New Delhi; 1982. p. 4-18. 